\author{
Bogumił Olczak ${ }^{10}$, Grzegorz Kowalski ${ }^{1,2}$, Sylwia Kropińska², Wojciech Leppert ${ }^{3}$, \\ Katarzyna Wieczorowska-Tobis ${ }^{2}$ \\ ${ }^{1}$ Department of Anaesthesiology, Józef Struś Municipal Hospital in Poznań \\ ${ }^{2}$ Chair and Clinic of Palliative Medicine, Karol Marcinkowski University of Medical Sciences in Poznań \\ ${ }^{3}$ Laboratory of Quality of Life Research, Chair and Clinic of Palliative Medicine, Karol Marcinkowski University \\ of Medical Sciences in Poznań
}

\title{
Knowledge of medical students on the use of opioids in the management of pain in patients receiving palliative care
}

\begin{abstract}
Introduction. Pre- and post-graduate education, provided for many years, has quite significantly changed the perception of the role of opioids in the treatment of patients with pain, mainly chronic pain. However, research on the knowledge of students on opioids has not been conducted, which makes it difficult to implement desired changes in educational programmes. The aim of the paper was to evaluate the knowledge of medical students on selected opioid drugs: tramadol, buprenorphine and oxycodone, based on a survey filled in after one-week classes in palliative medicine and pain management.

Respondents and methods. The study included 140 fourth-year students of medicine at the University of Medical Sciences in Poznań who completed one-week classes in palliative medicine and pain management. Their knowledge on opioid analgesics was checked using an anonymous survey that included 7 statements. Results. Students demonstrated better knowledge in statements regarding theoretical aspects of the use of specific opioids and their mechanisms of action. The percentage of correct answers in the group of statements concerning the availability of specific opioid analgesics was much lower, which confirms that they have less knowledge in this area.

Conclusions. Paying attention to the characteristics of specific opioids should improve the individual selection, effectiveness and safety of treatment. Better knowledge on pain management among students, doctors and the general public may dispel their concerns about using opioid analgesics as well as increase the effectiveness of pain management and improve the quality of life of patients with cancer and chronic pain in palliative care.
\end{abstract}

Palliat Med Pract 2020; 14, 4: 247-252

Key words: palliative care, pain, opioids, medical students, education

\section{Introduction}

Pain occurs in approx. $50-70 \%$ of patients with cancer, and the guidelines for the management of pain developed by the World Health Organization (WHO) allow for effective pain management in approx. 80-
$90 \%$ of patients with cancer [1]. Although Poland is one of the countries where palliative medicine is well developed, the use of opioid drugs is low compared to other European countries [2]. One of the reasons is insufficient knowledge of doctors and the phenomenon of opioidophobia.

\section{Address for correspondence:}

Bogumił Olczak

Department of Anaesthesiology and Intensive Care, Józef Struś Municipal Hospital in Poznań ul. Szwajcarska 3, 61-285 Poznań

tel.: +48 7923663 58; e-mail: bogumil.olczak@gmail.com

Palliative Medicine in Practice 2020; 14, 4, 247-252

Copyright (c) Via Medica, ISSN 2545-0425

DOI: 10.5603/PMPI.2020.0025 
Table 1. Survey with correct answers

1 Apart from the opioid mechanism, the analgesic effect of the drug results from the fact that it affects the descending antinociceptive system

2 If it is used with serotonergic inhibitors, the risk of serotonergic syndrome increases

3 It can be used in patients with moderate renal failure without changing the dosage due to the fact that the kidneys are not involved in eliminating the drug from the body

\begin{tabular}{|c|c|c|c|c|}
\hline 4 & The drug is available in preparations for subcutaneous use & $\mathrm{x}$ & $\mathrm{x}$ & $x$ \\
\hline 5 & It is available in preparations for intravenous administration & $\mathrm{x}$ & $\mathrm{x}$ & $\mathrm{x}$ \\
\hline 6 & It is available in extended-release oral preparations & $\mathrm{x}$ & & $\mathrm{x}$ \\
\hline 7 & $\begin{array}{l}\text { It is available in preparations with naloxone, recommended for } \\
\text { use in analgesic treatment, which is important in case of the } \\
\text { reduction of the risk of constipation }\end{array}$ & $\mathrm{x}$ & & \\
\hline & Sex & & & \\
\hline & Age & & & \\
\hline
\end{tabular}

The quality of pain management in patients with cancer has significantly improved since specialisation in palliative medicine was introduced in Poland. Excessive legal and administrative barriers to the prescription of opioid analgesics have also been reduced to a large extent [3]. Pre- and post-graduate education, provided for many years, has significantly changed the perception of the role of opioids in the treatment of patients with pain, mainly chronic pain. However, research on the knowledge of students on opioids has not been conducted, which makes it difficult to implement desired changes in educational programmes.

The aim of the study was to assess the knowledge of medical students on selected opioid analgesics (oxycodone, buprenorphine and tramadol), including available products, routes of administration and knowledge of side effects, based on the survey filled in after the completion of one-week classes in palliative medicine and pain management.

\section{Respondents and methods}

The study conducted in the Chair and Clinic of Palliative Medicine at the University of Medical Sciences in Poznań included 140 fourth-year students of medicine in the Faculty of Medicine at the University of Medical Sciences in Poznań who completed one-week classes in palliative medicine and pain management. The study was conducted in the 2019-2020 academic year, but it was disrupted in March 2020 by the COVID-19 pandemic.

Knowledge on opioid analgesics was checked using an anonymous survey that included 7 state- ments concerning 3 frequently used opioid analgesics: oxycodone, buprenorphine and tramadol. Students were asked to choose the drug(s) to which these statements apply. They were also asked not to use support materials and the Internet so that the answers reflect the actual state of knowledge. The survey along with the correct answers are presented in Table 1.

\section{Statistical analysis}

The results for each statement are presented as a percentage of correct answers. In case of statements with more than one correct answer, the percentage refers to those surveys in which all drugs meeting the condition under consideration were marked. In case of statements with one correct answer, an answer was considered to be correct for the drug meeting the condition under consideration if the drug in question was the only one that was marked.

Based on the above assumptions, an answer table was prepared for each student, in which specific statements for the analysed drugs were rated at 1 or 0 , depending on whether the given statement was correct or not. A maximum of 1 point was awarded for each answer. In this way, the opinions of students on individual opioids were quantified. The frequency of giving positive answers to each statement was compared using the $\mathrm{Chi}^{2}$ test.

Then the averages characterising the analysed drugs and standard deviations were calculated. The normality of distribution was evaluated based on the Shapiro-Wilk test. Due to the lack of normal distribution of variables, the median and range were also given in addition to the average and standard deviation. 
1. Apart from the opioid mechanism, the analgesic effect of the drug results from the fact that it affects the descending antinociceptive system

2. If it is used with serotonergic inhibitors, the risk of serotonergic syndrome increases

3. It can be used in patients with moderate renal failure without changing the dosage due to the fact that the kidneys are not involved in eliminating the drug from the body

4. The drug is available in preparations for subcutaneous use

5. It is available in preparations for intravenous administration

6. It is available in extended-release oral preparations

7. It is available in preparations with naloxone, recommended for use in analgesic treatment, which is important in case of the reduction of the risk of constipation

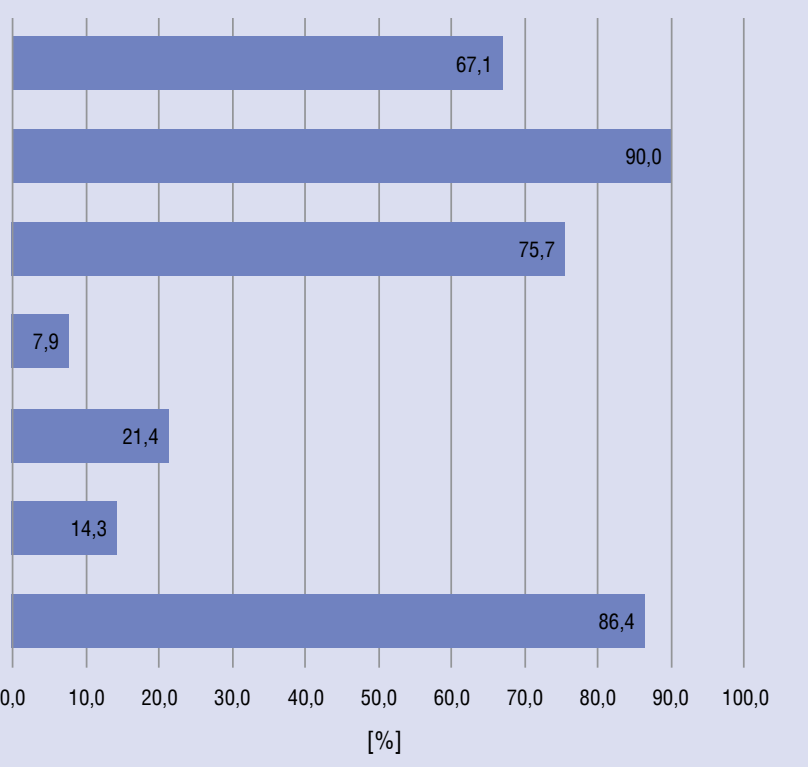

Figure 1. Percentage of correct answers in relation to survey statements $(n=140)$

The values obtained were compared by means of the ANOVA test using the Tukey's post-hoc test. The relationship between the results obtained by individual students for specific drugs was assessed (Spearman's correlation analysis). The value $p<0.05$ was assumed to be statistically significant.

\section{Results}

The average age of the students surveyed was $23.4 \pm 1.7$ years (range: $21-31$, median: 23 years). The respondents included 88 women $(62.9 \%)$ and 52 men (37.1\%).

The frequency of giving positive answers in relation to each statement is shown in Figure 1. A high percentage of correct answers is observed for statements related to theoretical knowledge on individual drugs and their mechanisms of action (statements 1-3) - in case of these statements, at least $2 / 3$ of the students gave correct answers. The second group includes statements concerning the availability of opioid analgesic products; in this group of questions, the percentage of correct answers, except for question 7, was much lower, and in case of statements 4-6, it was below $25 \%$.

The detailed analysis of the students' opinions on specific questions in relation to specific drugs (Figure 2) shows that in case of statements 5 and 6, the students gave correct answers significantly less frequently for buprenorphine than for the other two drugs $(p<0.001)$. Statistical significance was also demonstrated in statement 1 - oxycodone was more frequently indicated than tramadol, and in statement
7, where tramadol was more frequently selected than buprenorphine (in both cases $p<0.05$ ).

The average number of correct answers for oxycodone was $5.4 \pm 1.2$ (median 6.0, range: 2-7), and it was higher as compared to buprenorphine $4.6 \pm 1.0$ (median 5.0, range 1-7). The average number of correct answers for tramadol was $5.4 \pm 1.2$ (median 5.0, range 2-7), and it was higher than for buprenorphine. In both cases, the Tukey's test showed statistical significance at $p<0.001$.

There was a positive correlation between the number of correct answers given for oxycodone and tramadol: $r=0.3191, p<0.001$. No such correlation was observed for the following pairs: buprenorphine vs. tramadol ( $p=0.882$ ) and oxycodone vs. buprenorphine $(p=0.576)$.

\section{Discussion}

In view of longer overall survival time and increased incidence of cancer, the knowledge on pharmacological treatment of pain in patients with cancer is a very important issue in the field of palliative medicine and pain management. Opioid analgesics are an important element of effective treatment of chronic pain. In theory, medical students acquire knowledge in this field during classes in pharmacology and clinical pharmacology. Apart from theoretical knowledge, classes in palliative medicine give them the opportunity to learn about available opioid products and the practical aspects of using them in clinical practice. One of the aims of palliative medicine classes is to 
1. Apart from the opioid mechanism, the analgesic effect of the drug results from the fact that it affects the descending antinociceptive system 0 vs. T $p<0.05$

2. If it is used with serotonergic inhibitors, the risk of serotonergic syndrome increases

3. It can be used in patients with moderate renal failure without changing the dosage due to the fact that the kidneys are not involved in eliminating the drug from the body

4. The drug is available in preparations for subcutaneous use

5. It is available in preparations for intravenous administration 0 vs. $B p<0.001 ; B$ vs. T $p<0.001$

6. It is available in extended-release oral preparations 0 vs. $B p<0.001 ; B$ vs. T $p<0.001$

7. It is available in preparations with naloxone, recommended for use in analgesic treatment, which is important in case of the reduction of the risk of constipation B vs. T $p<0.05$

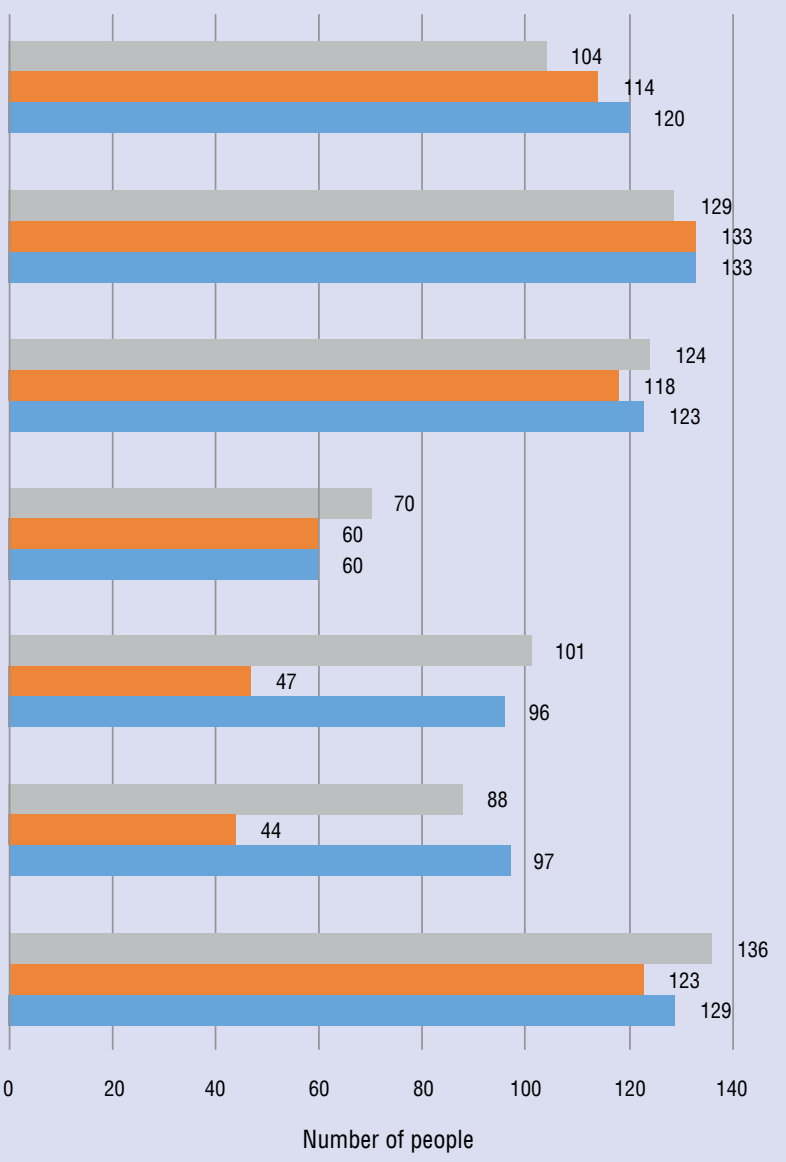

Number of people

\section{TRAMADOL BUPRENORFINA $\square$ OKSYKODON}

Figure 2. Number of correct answers for each question in relation to 3 drugs ( $\mathrm{O}$ - oxycodone, B - buprenorphine, $\mathrm{T}$ - tramadol), including both positive (the statement relates to a given drug) and negative (the statement does not relate to a given drug) answers

provide students with the knowledge to use opioids effectively and safely in clinical practice.

However, many people still fear the use of opioid analgesics, including doctors. Some doctors do not use opioids at all, either recommend too low doses or dose opioids in an inappropriate way, resulting in ineffective analgesia in patients with chronic pain [4]. This is probably because some doctors do not have sufficient knowledge concerning pain treatment with opioids and exaggerate the risk of side effects, including addiction [5].

The statements in the conducted survey concerned 3 frequently used opioid analgesics. Tramadol is the most commonly used step II opioid of the WHO analgesic ladder with a pain-relieving effect approx. 5-10 times lower compared to morphine. Tramadol exhibits a dual mechanism of analgesic effect: in addition to affecting the opioid receptors (mainly $\mu$ ) in CNS, it activates the descending antinocicep- tive system by inhibiting serotonin-norepinephrine reuptake [6].

Buprenorphine - a partial $\mu$ - and $\delta$-opioid receptor agonist, $\mathrm{k}$-opioid receptor antagonist - shows approx. 100 times more analgesic effect than morphine. Because of its significant lipophilicity, the drug is applied percutaneously in the form of patches affixed to the skin (Transdermal Therapeutic System [TTS]). Buprenorphine is characterized by low addiction potential and a favourable safety profile $[7,8]$.

Oxycodone is a semi-synthetic $\mu$ - and k-opioid receptor agonist, administered orally or parenterally (subcutaneously or intravenously). Oxycodone, along with morphine and hydromorphone, is the first choice opioid in the treatment of moderate-to-severe pain in cancer patients [9].

The statements have been prepared in such a way that the future doctor will know which guidelines to follow in choosing the right therapy for patient. The 
first group (statements 1-3) concerned the theoretical knowledge of opioids, mainly mechanisms of analgesic effect and principles of use. The second group (statements 4-7) concerned practical knowledge, i.e. the opioid products available for use in patients. One of the conclusions of the survey is that the theoretical knowledge of students was greater than practical knowledge. The knowledge of available opioid products among students is limited, the percentage of correct answers to statements 4-6 did not exceed $21.4 \%$. The exception is statement 7 , to which most students knew the correct answer. The combination of oxycodone with naloxone to reduce opioid-induced bowel dysfunction (OIBD) has been recognized and the product is frequently used, especially as it occurs in the form of prolonged-release tablets [10]. Buprenorphine is also available in combination with naloxone in the form of a sublingual tablet, but in the opioid substitution therapy (in Poland, however, methadone is mainly used).

The survey also showed students' greater knowledge of oxycodone than buprenorphine. This seems to be due to the fact that buprenorphine is mainly used subcutaneously (sublingually) and percutaneously in clinical practice, resulting in a lack of knowledge concerning other available forms of the drug.

There was a positive correlation between the number of correct answers given for oxycodone and tramadol, which means that students with more knowledge in relation to oxycodone responded better in statements concerning tramadol. However, no such correlation has been shown for combinations with buprenorphine, which seems to result from the previously discussed lack of knowledge concerning less frequently used forms of the drug.

The limitations of the conducted survey concern a small number of respondents - there were supposed to be more students. Due to the introduced restrictions related to COVID-19 pandemic, the study group could not be enlarged. Another limitation was the possibility of choosing more than one correct answer in the clinical statements (4-6), compared to the others, which could translate into a lower percentage of correct answers given. The original structure of the survey can also be treated as a limitation, but no standardized tool has been developed so far to evaluate students' knowledge concerning opioids. Another limitation of the survey is that two frequently used opioids - morphine and fentanyl to which other opioid drugs are often compared, were not included in the study.

Comparing the current survey with others [1113], which tested medical science students' knowledge of pain management, the obtained scores are similar. Modern teaching at Medical Universities should focus more on practical knowledge concerning the use of individual opioids and other chronic pain treatments.

\section{Conclusions}

Paying attention to the characteristics of specific opioids should improve the individual selection, effectiveness and safety of treatment. Better knowledge on pain management among students, doctors and the general public may dispel their concerns about using opioid analgesics as well as increase the effectiveness of pain management and improve the quality of life of patients with cancer and chronic pain in palliative care.

\section{Conflict of interests}

The Authors declares no conflict of interest.

\section{Funding}

This study has no funding.

\section{References}

1. Greco MT, Roberto A, Corli O, et al. Quality of cancer pain management: an update of a systematic review of undertreatment of patients with cancer. J Clin Oncol. 2014; 32(36): 4149-4154, doi: 10.1200/JCO.2014.56.0383, indexed in Pubmed: 25403222.

2. Dzierżanowski T, Ciałkowska-Rysz A. Accessibility of opioid analgesics and barriers to optimal chronic pain treatment in Poland in 2000-2015. Support Care Cancer. 2017; 25(3): 775-781, doi: 10.1007/s00520-016-3460-3, indexed in Pubmed: 27771783.

3. Leppert W, Pyszkowska J, Stachowiak A, et al. Dostępność leczenia opioidami w Polsce - na podstawie Ogólnopolskiej Konferencji w ramach Konsorcjum ATOME. Med Paliat. 2015; 7: 84-89.

4. Apolone G, Corli O, Caraceni A, et al. Cancer Pain Outcome Research Study Group (CPOR SG) Investigators. Pattern and quality of care of cancer pain management. Results from the Cancer Pain Outcome Research Study Group. Br J Cancer. 2009; 100(10): 1566-1574, doi: 10.1038/sj.bjc.6605053, indexed in Pubmed: 19401688.

5. Goldberg DS. On the erroneous conflation of opiophobia and the undertreatment of pain. Am J Bioeth. 2010; 10(11): 20-22, doi: 10.1080/15265161.2010.519427, indexed in Pubmed: 21104550.

6. Leppert W. Tramadol as an analgesic for mild to moderate cancer pain. Pharmacol Rep. 2009; 61(6): 978-992, doi: 10.1016/s1734-1140(09)70159-8, indexed in Pubmed: 20081232.

7. Schmidt-Hansen $M$, Taubert M, Bromham N, et al. The effectiveness of buprenorphine for treating cancer pain: an abridged Cochrane review. BMJ Support Palliat Care. 2016; 6(3): 292-306, doi: 10.1136/bmjspcare-2015-000939, indexed in Pubmed: 26669324.

8. Henningfield JE, Sun WZ. Concluding statement - neuropharmacological basis and clinical rationale for control of transdermal buprenorphine as a step II analgesic. Acta Anaesthesiol Taiwan. 2015; 53(2): 77-79, doi: 10.1016/j. aat.2015.05.002, indexed in Pubmed: 26068437. 
9. Schmidt-Hansen M, Bennett MI, Arnold S, et al. Oxycodone for cancer-related pain. Cochrane Database Syst Rev. 2015; 8(2): CD003870-128, doi: 10.1002/14651858.CD003870. pub5, indexed in Pubmed: 25723351.

10. Ahmedzai SH, Leppert W, Janecki $\mathrm{M}$, et al. Long-term safety and efficacy of oxycodone/naloxone prolonged-release tablets in patients with moderate-to-severe chronic cancer pain. Support Care Cancer. 2015; 23(3): 823-830, doi: 10.1007/s00520-014-2435-5, indexed in Pubmed: 25218610.

11. Neumann-Podczaska A, Tobis S, Yermukhanova L, et al. Pain in Advanced Stages of Dementia: The Perspective of Medical Students. Medicina (Kaunas). 2019; 55(5), doi: 10.3390/medicina55050116, indexed in Pubmed: 31035451.

12. Rucińska M, Kieszkowska-Grudny A, Sugajska A, et al. Wiedza studentów na temat stosowania opioidów w leczeniu przewlekłego bólu występującego u chorych na nowotwory. Palliat Med Pract. 2018; 12: 106-117.

13. Leppert W, Majkowicz M, Forycka M. Attitudes of Polish physicians and medical students toward breaking bad news, euthanasia and morphine administration in cancer patients. J Cancer Educ. 2013; 28(4): 603-610, doi: 10.1007/s13187013-0553-2, indexed in Pubmed: 24170311. 


\author{
Bogumił Olczak ${ }^{1}$, Grzegorz Kowalski ${ }^{1,2}$, Sylwia Kropińska², Wojciech Leppert ${ }^{3}$, \\ Katarzyna Wieczorowska-Tobis² \\ 'Oddział Anestezjologii, Szpital Miejski im. Józefa Strusia w Poznaniu \\ ${ }^{2}$ Katedra i Klinika Medycyny Paliatywnej, Uniwersytet Medyczny im. Karola Marcinkowskiego w Poznaniu \\ ${ }^{3}$ Pracownia Badania Jakości Życia, Katedra i Klinika Medycyny Paliatywnej, \\ Uniwersytet Medyczny im. Karola Marcinkowskiego w Poznaniu
}

\title{
Wiedza studentów medycyny dotycząca
}

\section{stosowania opioidów w leczeniu bólu}

\section{u chorych w opiece paliatywnej}

Artykuł jest tłumaczeniem pracy: Olczak B, Kowaliski G., Kropińska S., Leppert W., Wieczorowska-Tobis K., Knowledge of medical students on the use of opioids in the management of pain in patients receiving palliative care. Palliat. Med. Pract. 2020, tom 14, nr 4: 247-252

Należy cytować wersję pierwotną.

\section{Streszczenie}

Wstęp. Prowadzona od wielu lat edukacja przed- i podyplomowa, pozwoliła na dość istotną zmianę w postrzeganiu roli opioidów w leczeniu chorych z bólem, głównie przewlekłym. Jednak badania dotyczące wiedzy studentów na temat opioidów nie są wykonywane, co utrudnia wprowadzanie pożądanych zmian w programach edukacyjnych. Celem pracy była ocena wiedzy studentów medycyny na temat wybranych leków opioidowych: tramadolu, buprenorfiny i oksykodonu, na podstawie ankiety wypełnionej po zakończeniu tygodniowych zajęciach z zakresu medycyny paliatywnej i leczenia bólu.

Pacjenci i metody. Uczestnikami badania było 140 studentów IV roku medycyny Uniwersytetu Medycznego w Poznaniu po zakończeniu tygodniowych zajęć z zakresu medycyny paliatywnej i leczenia bólu. Wiedza na temat opioidowych leków przeciwbólowych była sprawdzana za pomocą anonimowej ankiety złożonej z 7 stwierdzeń.

Wyniki. Studenci wykazali lepszą wiedzę w stwierdzeniach dotyczących teoretycznych aspektów stosowania poszczególnych opioidów i mechanizmów ich działania. W grupie stwierdzeń dotyczących dostępności poszczególnych produktów analgetyków opioidowych odsetek prawidłowych odpowiedzi był znacznie niższy, co wskazuje na mniejszą wiedzę w tym zakresie.

Wnioski. Zwrócenie uwagi na charakterystykę poszczególnych opioidów, co powinno poprawić indywidulany dobór, skuteczność i bezpieczeństwo terapii. Większa wiedza dotycząca leczenia bólu wśród studentów, lekarzy i ogółu społeczeństwa może zmniejszyć obawy dotyczące analgetyków opioidowych, a poprzez prawidłowe ich stosowanie, zwiększyć skuteczność leczenia bólu i poprawić jakość życia chorych na nowotwory i z bólem przewlekłym innego pochodzenia w opiece paliatywnej.

Palliat Med Pract 2020; 14, 4: 253-258

Słowa kluczowe: opieka paliatywna, ból, opioidy, studenci medycyny, edukacja

\section{Adres do korespondencji:}

Bogumił Olczak

Oddział Anestezjologii i Intensywnej Terapii, Szpital Miejski im. Józefa Strusia w Poznaniu ul. Szwajcarska 3, 61-285 Poznań

tel.: +4879 23663 58, e-mail: bogumil.olczak@gmail.com 
Tabela 1. Ankieta wraz z zaznaczonymi prawidłowymi odpowiedziami

\begin{tabular}{|c|c|c|c|c|}
\hline & & OKSYDON & BUPRENORFINA & TRAMADOL \\
\hline 1 & $\begin{array}{l}\text { Działanie przeciwbólowe leku wynika - poza mechanizmam } \\
\text { opioidowym - także z oddziaływania na układ } \\
\text { antynocyceptywny zstępujący }\end{array}$ & & & $\mathrm{x}$ \\
\hline 2 & $\begin{array}{l}\text { Wspólne stosowanie z inhibitorami serotoninergicznymi } \\
\text { zwiększa ryzyko zespołu serotoninergicznego }\end{array}$ & & & $\mathrm{x}$ \\
\hline 3 & $\begin{array}{l}\text { Może być stosowany u chorych z umiarkowaną niewydolnościa } \\
\text { nerek bez zmiany dawkowania ze względu na to, że nerki nie } \\
\text { odgrywają roli w eliminacji leku z ustroju }\end{array}$ & & $\mathrm{x}$ & \\
\hline 4 & Lek jest dostępny w preparatach do stosowania podskórnego & $x$ & $x$ & $\mathrm{x}$ \\
\hline 5 & Jest dostępny w preparatach do podawania dożylnego & $\mathrm{x}$ & $\mathrm{x}$ & $\mathrm{x}$ \\
\hline 6 & $\begin{array}{l}\text { Jest dostępny w preparatach doustnych o przedłużonym } \\
\text { uwalnianiu }\end{array}$ & $\mathrm{x}$ & & $\mathrm{x}$ \\
\hline \multirow[t]{3}{*}{7} & $\begin{array}{l}\text { Jest dostępny w preparatach z naloksonem wskazanych do } \\
\text { leczenia przeciwbólowego co ma znaczenie dla zmniejszenia } \\
\text { ryzyka zaparć }\end{array}$ & $\mathrm{x}$ & & \\
\hline & Płeć & & & \\
\hline & Wiek .......... & & & \\
\hline
\end{tabular}

\section{Wstęp}

Ból występuje u około $50-70 \%$ u chorych na nowotwory, a zasady leczenia przeciwbólowego opracowane przez Światową Organizację Zdrowia (WHO, World Health Organization) pozwalają na skuteczne leczenie bólu u ok. 80-90\% chorych na nowotwory [1]. Pomimo że Polska zalicza się do krajów, w których medycyna paliatywna jest dobrze rozwinięta, zużycie leków opioidowych w porównaniu do innych krajów europejskich jest niewielkie [2]. Jedną z przyczyn stanowi niedostateczna wiedza lekarzy i zjawisko opioidofobii.

Wprowadzenie specjalizacji z medycyny paliatywnej w Polsce spowodowało istotną poprawę jakości leczenia bólu u chorych na nowotwory. W znacznej mierze udało się ograniczyć nadmierne bariery prawne i administracyjne utrudniające zapisywanie opioidowych leków przeciwbólowych [3]. Prowadzona od wielu lat edukacja przed- i podyplomowa, pozwoliła na istotną zmianę $w$ postrzeganiu roli opioidów w leczeniu chorych z bólem, głównie przewlekłym. Jednak badania dotyczące wiedzy studentów medycyny na temat opioidów nie są wykonywane, co utrudnia wprowadzanie pożądanych zmian w programach edukacyjnych.

Celem badania była ocena wiedzy studentów medycyny dotyczącej wybranych opioidowych leków przeciwbólowych (oksykodonu, buprenorfiny i tramadolu), w tym dostępnych produktów, drogi podawania i znajomości działań niepożądanych, na podstawie ankiety wypełnianej po zakończeniu tygodniowych zajęć z zakresu medycyny paliatywnej i leczenia bólu.

\section{Badani i metody}

Uczestnikami badania było 140 studentów IV Roku wydziału lekarskiego Uniwersytetu Medycznego w Poznaniu po zakończeniu tygodniowych zajęć z zakresu medycyny paliatywnej i leczenia bólu przeprowadzonego w Katedrze i Klinice Medycyny Paliatywnej Uniwersytetu Medycznego w Poznaniu. Badanie prowadzono w roku akademickim 2019/2020, jednak w marcu 2020 roku z powodu pandemii COVID-19 zostało przerwane.

Wiedza na temat opioidowych leków przeciwbólowych była sprawdzana za pomocą anonimowej ankiety złożonej z 7 stwierdzeń, które dotyczyły 3 często stosowanych analgetyków opioidowych: oksykodonu, buprenorfiny i tramadolu. Studentów poproszono o zaznaczenie leku/leków, którego/których te stwierdzenia dotyczą. Poproszono także o niekorzystanie z materiałów pomocniczych i Internetu, aby odpowiedzi odzwierciedlały faktyczny stan wiedzy. Treść ankiety wraz z zaznaczonymi prawidłowymi odpowiedziami przedstawiono w tabeli 1 .

\section{Analiza statystyczna}

Wyniki dla poszczególnych stwierdzeń przedstawiono w postaci odsetka odpowiedzi prawidłowych. Dla stwierdzeń z więcej niż jedną odpowiedzią prawidłową, odsetek odnosi się do ankiet, w których zaznaczono wszystkie leki spełniające rozpatrywany warunek. Dla stwierdzeń z jedną prawidłową odpowiedzią, uznano ją za prawidłową dla leku spełniającego opisany warunek, jeśli został 
1. Działanie przeciwbólowe leku wynika - poza mechanizmam opioidowym - także z oddziaływania na układ antynocyceptywny zstępujący

2. Wspólne stosowanie z inhibitorami serotoninergicznymi zwiększa ryzyko zespołu serotoninergicznego

3. Może być stosowany u chorych z umiarkowaną niewydolnościa nerek bez zmiany dawkowania ze względu na to, że nerki nie odgrywają roli w eliminacji leku z ustroju

4. Lek jest dostępny w preparatach do stosowania podskórnego

5. Jest dostępny w preparatach do podawania dożylnego

6. Jest dostępny w preparatach doustnych o przedłużonym uwalnianiu

7. Jest dostępny w preparatach z naloksonem wskazanych do leczenia przeciwbólowego co ma znaczenie dla zmniejszenia ryzyka zaparć

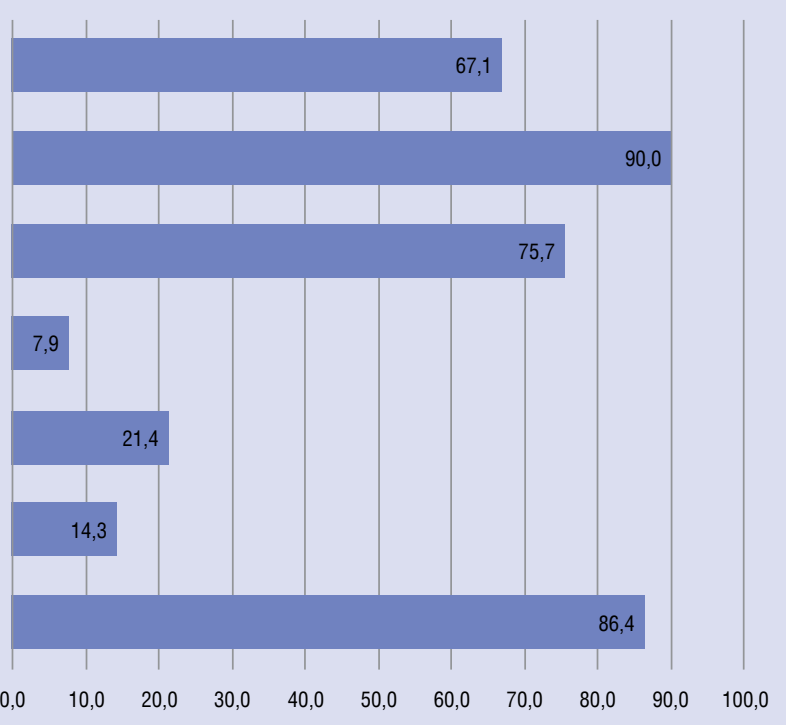

$[\%]$

Rycina 1. Odsetek prawidłowych odpowiedzi w odniesieniu do stwierdzeń ankiety $(n=140)$

on zaznaczony, ale pozostałe leki nie zostały zaznaczone.

W oparciu o powyższe założenia przygotowano tabelę odpowiedzi dla każdego studenta, w której poszczególnym stwierdzeniom dla analizowanych leków przyznano 1 lub 0, w zależności, czy dla danego stwierdzenia udzielona odpowiedź jest prawidłowa, czy nie. Wszystkie odpowiedzi zostały ocenione na 1 punkt. W ten sposób scharakteryzowano liczbowo opinie studentów na temat poszczególnych opioidów. Częstość udzielania pozytywnych odpowiedzi dla poszczególnych stwierdzeń porównano testem $\mathrm{Chi}^{2}$.

Następnie wyliczono średnie charakteryzujące analizowane leki i odchylenia standardowe. Zbadano normalność rozkładu testem Shapiro-Wilka. Z powodu braku rozkładu normalnego zmiennych podano, poza średnią i odchyleniem standardowym, również medianę i zakres. Uzyskane wartości porównano testem ANOVA, stosując test post-hoc Tukeya. Oceniano występowanie związku pomiędzy uzyskiwanymi przez poszczególnych studentów wynikami dla poszczególnych leków (analiza korelacji Spearmana). Wartość $\mathrm{p}<0,05$ przyjęto jako istotną statystycznie.

\section{Wyniki}

Średni wiek badanych studentów wynosił 23,4 \pm 1,7 lat (zakres: 21-31, mediana 23 lata). Wśród badanych było 88 (62,9\%) kobiet i $52(37,1 \%)$ mężczyzn.

Częstość udzielania prawidłowych odpowiedzi w odniesieniu do poszczególnych stwierdzeń przed- stawiono na rycinie 1. Zwraca uwagę wysoki odsetek prawidłowych odpowiedzi dla stwierdzeń wiedzy teoretycznej dotyczącej poszczególnych leków i mechanizmów ich działania (stwierdzenia 1-3) - dla tych stwierdzeń, co najmniej 2/3 studentów udzieliło poprawnej odpowiedzi. Drugą grupę stanowią stwierdzenia dotyczące dostępności produktów analgetyków opioidowych, w tej grupie pytań odsetek prawidłowych odpowiedzi, poza pytaniem 7, był znacznie niższy i w stwierdzeniach 4-6 i wynosił poniżej 25\%.

Analizując szczegółowo opinie studentów na temat poszczególnych pytań w odniesieniu do konkretnych leków (ryc. 2) zauważyć można, że dla stwierdzenia 5 i 6 studenci udzielali istotnie rzadziej prawidłowe odpowiedzi dotyczące buprenorfiny, w porównaniu do dwóch pozostałych leków $(p<0,001)$. Istotność statystyczną wykazano również w stwierdzeniu 1 - częściej wskazywano na oksykodon niż na tramadol i stwierdzeniu 7, gdzie częściej wybierano tramadol niż buprenorfinę (w obydwu przypadkach $\mathrm{p}<0,05)$.

Na 7 możliwych prawidłowych odpowiedzi, średnia liczba dla oksykodonu wynosiła 5,4 \pm 1,2 (mediana 6,0, zakres: 2-7) i była wyższa w porównaniu do buprenorfiny 4,6 $\pm 1,0$ (mediana 5,0, zakres 1-7). Średnia liczba poprawnych odpowiedzi dla tramadolu wynosiła 5,4 \pm 1,2 (mediana 5,0, zakres 2-7) i była również wyższa niż dla buprenorfiny. W obu przypadkach w teście Tukeya wykazano istotność statystyczną przy $\mathrm{p}<0,001$.

Stwierdzono pozytywną korelację pomiędzy liczbą poprawnych odpowiedzi udzielanych dla oksykodonu 
1. Działanie przeciwbólowe leku wynika - poza mechanizmam opioidowym - także z oddziaływania na układ antynocyceptywny zstępujący 0 vs. T $p<0.05$

2. Wspólne stosowanie z inhibitorami serotoninergicznymi zwiększa ryzyko zespołu serotoninergicznego

3. Może być stosowany u chorych z umiarkowaną niewydolnościa nerek bez zmiany dawkowania ze względu na to, że nerki nie odgrywają roli w eliminacji leku z ustroju

4. Lek jest dostępny w preparatach do stosowania podskórnego

5. Jest dostępny w preparatach do podawania dożylnego 0 vs. $B p<0.001 ; B$ vs. T $p<0.001$

6. Jest dostępny w preparatach doustnych o przedłużonym uwalnianiu

0 vs. $B p<0.001 ; B$ vs. T $p<0.001$

7. Jest dostępny w preparatach z naloksonem wskazanych do leczenia przeciwbólowego co ma znaczenie dla zmniejszenia ryzyka zaparć

B vs. T $p<0.05$
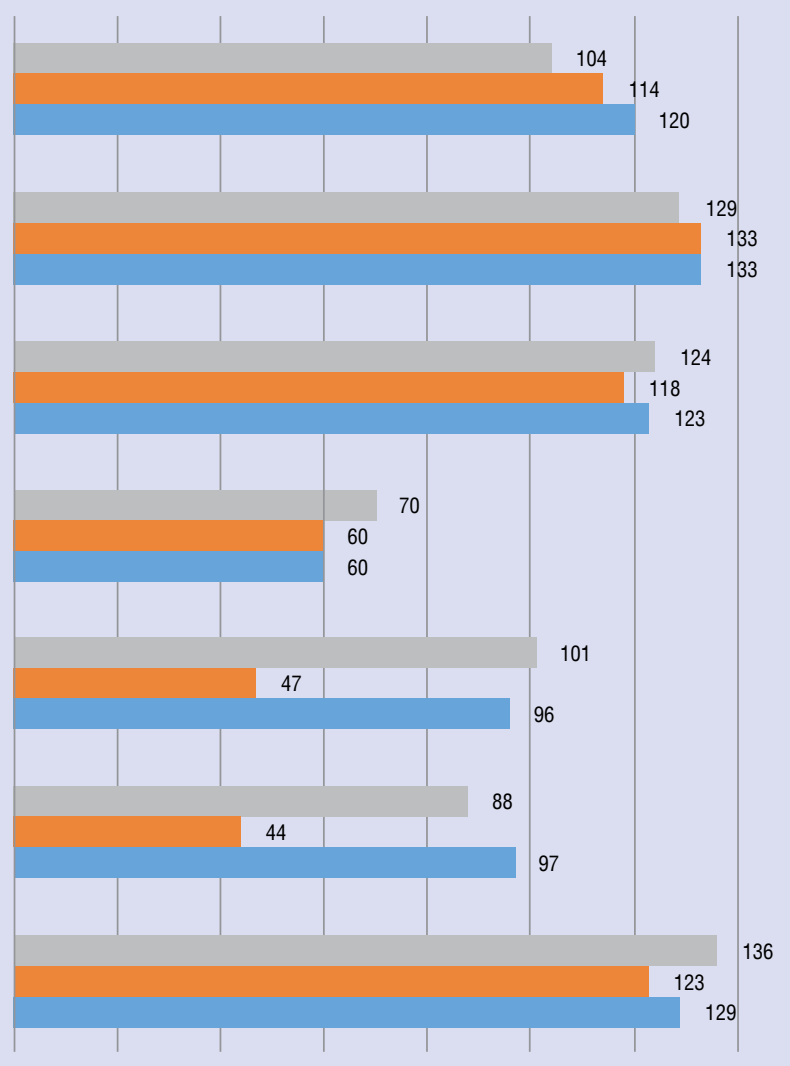

$60-80$

Number of people

TRAMADOL BUPRENORFINA

Rycina 2. Liczba prawidłowych odpowiedzi dla każdego pytania, z uwzględnieniem 3 leków (O — oksykodon, B - buprenorfina, T - tramadol) zarówno pozytywnych (stwierdzenie występuje dla danego leku), jak i negatywnych (stwierdzenie nie występuje dla danego leku)

i tramadolu: $r=0,3191, p<0,001$. Nie wykazano takiej korelacji dla par buprenorfina vs. tramadol $(p=0,882)$ i oksykodon vs. buprenorfina $(p=0,576)$.

\section{Dyskusja}

Wobec dłuższego całkowitego czasu przeżycia i wzrostu zapadalności na nowotwory wiedza dotycząca leczenia farmakologicznego bólu u chorych na nowotwory stanowi bardzo istotne zagadnienie medycyny paliatywnej i medycyny bólu. Istotny element skutecznego leczenia bólu przewlekłego stanowią analgetyki opioidowe. Edukacja studentów medycyny w tym zakresie odbywa się teoretycznie na zajęciach z farmakologii i farmakologii klinicznej. Zajęcia z zakresu medycyny paliatywnej dają możliwość uzyskania, oprócz wiedzy teoretycznej, zapoznania się z praktycznymi aspektami stosowania w praktyce klinicznej i dostępnymi produktami opioidów. Jednym z celów zajęć z zakresu medycyny paliatywnej jest uzyskanie przez studentów wiedzy pozwalającej na skuteczne i bezpieczne stosowanie opioidów w praktyce klinicznej.

Jednak nadal wiele osób obawia się stosowania analgetyków opioidowych, co dotyczy również lekarzy. Niektórzy lekarze w ogóle nie stosują opioidów, bądź zalecają zbyt małe dawki lub w niewłaściwy sposób dawkują opioidy, co powoduje nieskuteczną analgezję u chorych na cierpiących z powodu przewlekłego bólu [4]. Dzieje się tak prawdopodobnie dlatego, iż część lekarzy nie posiada dostatecznej wiedzy na temat leczenia bólu opioidami i wyolbrzymia ryzyko wystąpienia działań niepożądanych, w tym także uzależnienia [5].

Stwierdzenia w przeprowadzonej ankiecie dotyczyły 3 często stosowanych analgetyków opioidowych. Tramadol jest najczęściej stosowanym opioidem II stopnia drabiny analgetycznej WHO o efekcie przeciwbólowym około 5-10 razy słabszym w porównaniu do morfiny. Tramadol wykazuje podwójny mechanizm 
działania przeciwbólowego: oprócz oddziaływania na receptory opioidowe (głównie $\mu$ ) w OUN, aktywuje zstępujący układ antynocyceptywny poprzez zahamowanie wychwytu zwrotnego serotoniny i noradrenaliny [6].

Buprenorfina jest częściowym agonistą receptora opioidowego $\mu \mathrm{i} \delta$, antagonistą receptora opioidowego $\mathrm{k}$, wykazuje około 100-krotnie silniejszy efekt analgetyczny w porównaniu z morfiną. Ze względu na znaczną lipofilność lek jest stosowany drogą przezskórną w postaci plastrów naklejanych na skórę (transdermalny system terapeutyczny [TTS, Transdermal Therapeutic System]). Buprenorfinę cechuje niski potencjał wywołania uzależnienia i korzystny profil bezpieczeństwa $[7,8]$.

Oksykodon to półsyntetyczny agonista receptorów opioidowych $\mu \mathrm{i}$ k, podawany drogą doustną bądź parenteralną (podskórną lub dożylną). Oksykodon, obok morfiny i hydromorfonu, jest opioidem pierwszego wyboru w leczeniu bólu o umiarkowanym do silnego natężeniu u chorych na nowotwory [9].

Stwierdzenia zostały przygotowane w taki sposób, aby przyszły lekarz wiedział czym może się kierować przy wyborze odpowiedniej terapii dla pacjenta. Pierwsza grupa (stwierdzenia 1-3) dotyczyła wiedzy teoretycznej opioidów, głównie mechanizmów działania przeciwbólowego i zasad stosowania. Druga grupa (stwierdzenia 4-7) dotyczyła wiedzy praktycznej, czyli produktów opioidów dostępnych do stosowania u pacjentów. Jednym z wniosków przeprowadzonego badania jest fakt, że wiedza teoretyczna studentów była większa niż wiedza praktyczna. Wiedza o dostępnych produktach opioidów wśród studentów jest ograniczona, odsetek poprawnych odpowiedzi stwierdzeń 4-6 nie przekroczył 21,4\%. Wyjątek stanowi stwierdzenie 7, na które większość studentów znała prawidłową odpowiedź. Połączenie oksykodonu z naloksonem, celem ograniczenia poopiodowych zaburzeń jelitowych (OIBD, opioid-induced bowel dysfunction), znalazło uznanie i produkt jest często stosowany zwłaszcza, iż występuje w postaci tabletek o przedłużonym uwalnianiu [10]. Buprenorfina jest również dostępna w połączeniu z naloksonem $w$ formie tabletki do podawania drogą podjęzykową, ale w leczeniu substytucyjnym uzależnienia od opioidów (w Polsce jednak głównie stosowany jest metadon).

W badaniu wykazano również większą wiedzę studentów odnośnie oksykodonu niż buprenorfiny. Wydaje się to wynikać $z$ tego, że buprenorfina w praktyce klinicznej jest stosowana głównie w postaci podjęzykowej i przezskórnej, co skutkuje brakiem wiedzy o innych dostępnych postaciach leku.

Stwierdzono pozytywną korelację pomiędzy liczbą poprawnych odpowiedzi udzielanych dla oksykodonu i tramadolu, co oznacza, iż studenci wykazujący większą wiedzę w stosunku do oksykodonu odpowiadali lepiej w stwierdzeniach dotyczących tramadolu. Natomiast nie wykazano takiej korelacji dla par z buprenorfiną, co wydaje się wynikać $z$ omawianego wcześniej braku wiedzy o rzadziej stosowanych postaciach leku.

Ograniczenia przeprowadzonego badania dotyczą niewielkiej liczby respondentów - w założeniu ankietowanych studentów miało być więcej. Ze względu na wprowadzone ograniczenia związane z pandemią COVID-19 nie udało się powiększyć grupy badanej. Kolejnym ograniczeniem była możliwość wyboru więcej niż jednej odpowiedzi prawidłowej w stwierdzeniach klinicznych (4-6), w porównaniu z pozostałymi, co mogło się przełożyć na niższy odsetek udzielonych poprawnych odpowiedzi. Jako ograniczenie można potraktować konstrukcję własną ankiety, jednak do tej pory nie opracowano wystandaryzowanego narzędzia służącego do oceny wiedzy studentów na temat opioidów. Kolejnym ograniczeniem badania jest to, że nie uwzględniono w badaniu dwóch często stosowanych opioidów - morfiny i fentanylu, do których często się porównuje inne leki opioidowe.

Porównując obecne badanie z innymi [11-13], w których sprawdzano wiedzę studentów nauk medycznych z zakresu leczenia bólu, wnioski z uzyskanych wyników są podobne. Nowoczesne nauczanie na Uniwersytetach Medycznych powinno w większym stopniu dotyczyć wiedzy praktycznej dotyczącej stosowania poszczególnych opioidów i innych metod leczenia bólu przewlekłego.

\section{Wnioski}

Zwrócenie uwagi na charakterystykę poszczególnych opioidów, co powinno poprawić indywidulany dobór, skuteczność i bezpieczeństwo terapii. Większa wiedza dotycząca leczenia bólu zarówno wśród studentów, lekarzy, jak i ogółu społeczeństwa może zmniejszyć obawy dotyczące analgetyków opioidowych, a poprzez prawidłowe ich stosowanie, zwiększyć skuteczność leczenia bólu i poprawić jakość życia chorych na nowotwory i z bólem przewlekłym innego pochodzenia w opiece paliatywnej.

\section{Konflikt interesów}

Autorzy deklarują brak konfliktu interesów.

\section{Finansowanie}

Badanie nie było finansowane.

\section{Piśmiennictwo}

1. Greco MT, Roberto A, Corli O, et al. Quality of cancer pain management: an update of a systematic review of 
undertreatment of patients with cancer. J Clin Oncol. 2014;32(36):4149-4154. doi:10.1200/JCO.2014.56.0383

2. Dzierżanowski T, Ciałkowska-Rysz A. Accessibility of opioid analgesics and barriers to optimal chronic pain treatment in Poland in 2000-2015. Supportive Care in Cancer 2017; 25: 775-781. doi:10.1007/s00520-016-3460-3.

3. Leppert W, Pyszkowska J, Stachowiak A, Krajnik M, Bartnik M. Dostępność leczenia opioidami w Polsce - na podstawie Ogólnopolskiej Konferencji w ramach Konsorcjum ATOME. Med Paliat 2015; 7: 84-89.

4. Apolone G, Corli O, Caraceni A, et al. Cancer Pain Outcome Research Study Group (CPOR SG) Investigators. Pattern and quality of care of cancer pain management. Results from the Cancer Pain Outcome Research Study Group. Br J Cancer 2009; 100: 1566-1574. doi:10.1038/sj.bjc.6605053

5. Goldberg DS. On the erroneous conflation of opioidophobia and the undertreatment of pain. Am J Bioeth 2010; 10: 20-22. doi:10.1080/15265161.2010.519427.

6. Leppert W. Tramadol as an analgesic for mild to moderate cancer pain. Pharmacol Rep 2009; 61: 978992. doi:10.1016/s1734-1140(09)70159-8.

7. Schmidt-Hansen M., Taubert M., Bromham N., Hilgart J.S., Arnold $\mathrm{S}$. The effectiveness of buprenorphine for treating cancer pain: an abridged Cochrane review. BMJ Support Palliat Care 2016; 6: 292-306. doi:10.1136/bmjspcare-2015-000939.

8. Henningfield JE, Sun WZ. Concluding statement - neuropharmacological basis and clinical rationale for control of transdermal buprenorphine as a step II analgesic. Acta Anaesthesiol Taiwan 2015: 53: 77-79. doi:10.1016/j. aat.2015.05.002.

9. Schmidt-Hansen M, Bennett MI, Arnold S, Bromham N, Hilgart JS. Oxycodone for cancer-related pain. Cochrane Database Syst Rev 2015 Feb 27; (2): CD003870. doi:10.1002/14651858.CD003870.pub6.

10. Ahmedzai SH, Leppert W, Janecki M, Pakosz A, Lomax $M$, Duerr $H$, Hopp M. Long-term safety and efficacy of oxycodone/naloxone prolonged-release tablets in patients with moderate-to-severe chronic cancer pain. Support Care Cancer 2015; 23: 823-830. doi:10.1007/s00520014-2435-5.

11. Neumann-Podczaska A, Tobis S, Yermukhanova L, Wieczorowska-Tobis K. Pain in Advanced Stages of Dementia: The Perspective of Medical Students. Medicina (Kaunas). 2019; 55: 116. doi:10.3390/medicina55050116.

12. Rucińska M, Kieszkowska-Grudny A, Sugajska A, Osowiecka K, Siwy-Hudowska A. Wiedza studentów na temat stosowania opioidów w leczeniu przewlekłego bólu występującego u chorych na nowotwory. Palliat Med Pract 2018; 12: 106-117.

13. Leppert W, Majkowicz M, Forycka M. Attitudes of Polish physicians and medical students toward breaking bad news, euthanasia and morphine administration in cancer patients. J Cancer Educ 2013; 28 (4): 603-610. doi: 10.1007/s13187-013-0553-2 